\title{
THE ROLE PLAYED BY THE ARMED FORCES FOR PROTECTION OF THE CIVILIAN POPULATION AS PART OF HUMANITARIAN CRISES MANAGEMENT. THE ROMANIAN APPROACH
}

\author{
Aurelian RAȚIU, Assoc. Prof. PhD \\ e-mail: ratiu.aurelian@armyacademy.ro \\ Ghiță BÂRSAN, Professor PhD, Eng. \\ e-mail: gbarsan@armyacademy.ro \\ Marioara PATESAN, Professor PhD \\ e-mail: patesan.marioara@armyacademy.ro \\ "Nicolae Bălcescu" Land Forces Academy, Sibiu, Romania \\ Dorin IONIȚĂ, PhD \\ e-mail: dorinionita26@yahoo.com \\ Ministry of Defence, General Staff Headquarters, Bucharest, Romania
}

\begin{abstract}
The actions of the military structures to protect the civilian population have evolved from air defence operations to complex missions of "human security", based on prevention and intervention in any civil emergency situation facing a community. Our prospective undertakings have highlighted the necessity to integrate traditional civil defence actions with modern actions taken to manage emergencies against all kinds of hazards.

The profound transformations of contemporary society and of the military body, in the context of the new risks and threats to the international security environment, required the remodelling of the role of the military instrument.

The consequences of the combined military and non-military risks and threats can seriously affect the capacity to respond to evolutionary forms of their manifestation by diminishing the human, technical, material and financial resources, the sudden decrease of the standard of living and the citizens' trust in the state institutions with a decisional role in the field of national security.
\end{abstract}


Thus, in order to accomplish the specific missions of these circumstances, the main question is: under what conditions can the armed forces cooperate with the civil protection structures, as well as with the other elements of national public security and safety system, focused on fighting against risk and threats specific to emergency situations?

In this respect, this paper intends to present a number of particular aspects regarding the role and relevance of military intervention in humanitarian crisis management for the protection of the civilian population along with other specialist structures.

Key words: Armed Forces, population protection, military intervention, humanitarian crises management, civil-military integration

\section{Introductory and methodological issues}

Society, in its entirety, is a system, and its components are subsystems. The army is one of these subsystems, in its capacity as a social entity designed to carry out activities targeted towards achieving objectives, deliberately structured and having identifiable limits (Iacob and Cismaru 2002, p. 12) The army is also a social entity, an important component of the nation, with relatively stable statuses and roles, as it is meant to meet certain people's needs in society or to fulfil certain social functions.

For this purpose, it maintains close relations with the social and political environment. Moreover, the army is subordinated exclusively to the will of the people (The Constitution of Romania 2003, art 118, para 1), and the basic role the army has in society, as a specialist tool, is to organise the defence of the country, implicitly of its population.

The army is the state institution that manages violence lawfully and within the limits imposed by the law, to carry out its missions. In this regard, it has a specific organisation, qualified staff, various fighting means, normative acts justifying its existence and use of violence, mainly in carrying out the tasks entrusted to secure the sovereignty, independence and unity of the state, the territorial integrity of the country and the constitutional democracy (The Constitution of Romania 2003, art 118 , para 1 ). 
At the same time, the army's missions can be seen as a concrete, appropriate and flexible response to the promotion and defence of national interests, especially those of security, both inside and outside the country (Law no. 346/2006 regarding the Organization and Functioning of the Ministry of National Defense, art. 34). The Army's missions are also a way of connecting the armed forces as a subsystem to the society as a general system, as well as with other state institutions with attributions in the fields of national and human security.

In this respect, besides the general missions related to the guarantee of sovereignty, independence and unity of the state, territorial integrity of the country and constitutional democracy, the army, according to the Romanian Military Doctrines in use (Land Forces Operations Doctrine 2004, art. 1134), is able to carry out other types of actions and activities of active and consistent involvement of the military units and subunits for the protection of the population in the event of natural calamities (floods, devastating fires, strong earthquakes, blizzards, massive landslides), ecological catastrophes and other situations in which only the intervention of specialist army structures can solve the problems that may occur.

In fact, all the national armies have to assume such types of missions, irrespective of the size, population, economic and military power of that state.

Our main hypothesis was as follows: the better the components of contemporary transformational processes and their implications in the military domain are known, the better the factors underlying the political and military decisions with a major impact on the management and resolution of a crisis situation can lead to, more precisely, the doctrinary-action conception of military intervention.

Critical analysis was the research method used in order to distinguish through valid arguments what is positive and realistic from what is wrong and harmful in crisis management, approaching it from the perspective of civilian protection by the army. Everything has been related to the involvement of the military instrument in the efforts to achieve the objectives set out in national strategies and international commitments.

Another important criterion of our research was the objective assessment of the given issue, without prejudgments or conjunctural interpretations, relating doctrinaire-operational aspects to the actual strategic environment. Factors have 
been taken into account here such as: risks and threats, management evolution as well as new approaches in the field of technologies and other sciences (comprehensive approach).

The analysis was predominantly a theoretical one, based on induction and logical argumentation, thus attempting to emphasise the essence of the studied phenomena, to depict reality, to identify lessons learned and conclusions that define the role of the military in the protection of the civilian population in crisis situations.

\section{Concepts specific to the intervention of military structures for the defence of the civilian population}

Throughout the history of human societies, many degenerative factors have manifested themselves, having disrupted, sometimes with major effects, the state of equilibrium, of normality. The multitude of the situations caused by processes that are difficult or even impossible to manage, with genesis, spheres of influence and diverse consequences, highlights the fact that there is no social organisation, no matter its temporal and spatial location, or any field of activity that has developed linearly, without syncopes. These syncopes are defined in contemporary analytical language as "emergency situations", "crisis situations", "social crises", etc. In their dynamics and complexity, the crises ${ }^{1}$ accompanied the general evolution of humanity and decisively influenced their physiognomy.

Thus, in terms of maximum coverage, the crisis is an unexpected change, often decisive, favourable or unfavourable to society, with a short reaction time, violent manifestation, a dangerous period for the existence of an organisation, and a shortage or a failure of something (Neag 2007, p. 142).

In other words, no society/organisation has developed or evolved without being influenced by stagnations or involutions generating physical and social insecurity.

1 The crisis is a phase in the evolution of a society, marked by major difficulties (political, social, economic, ecological, etc.); a period of tension, of disorder, of attempts (often decisive) that manifest in the society (cf. Dicționarul Explicativ al Limbii Române 2009, p. 251). 
These dysfunctions of human activity, on the whole, have causes and multiple effects whose analysis depends on the perception of the context and the sphere of coverage and the depth of the perspective from which their study is approached.

Due to the climate of uncertainty regarding the evolution and precise determination of the consequences of the decisions, crisis management becomes an absolute priority in the context of the drastic diminishing of the time for analysis of the factors of the situation. From this perspective, the crisis is a mutation in the external and internal environment; a threat to the core values; a high probability of engaging in hostilities with a predominantly military character (Neag, pp. 143-144). Furthermore, the daily language and the specialised literature have been enriched in recent years with new notions and expressions such as: tragedy, natural disaster humanitarian catastrophe, humanitarianassistance, humanitarianaid, humanitarianoperations, humanitarian intervention, humanitarian missions and routes, humanitarian transportation, etc. All these reflect the crisis situations that can arise in human communities where it is particularly important that people in need, due to natural disasters or caused by human activities and military conflicts, should be helped to overcome the moment of crisis by reducing the effects of the disaster they have been subjected to, by alleviating the suffering of the victims and by providing basic survival conditions (Dragoman, Istrătescu and Bulete 2017).

Another reference concept is the emergency situation. According to the Romanian norms in force, the emergency situation "is an exceptional event, with a nonmilitary character, which, by its size and intensity, threatens the life and health of the population, the environment, important material and cultural values, and to restore a normal state, it is necessary to adopt urgent measures and actions and allocate additional resources and the unitary management of the forces and means involved" (Romanian Government Emergency Ordinance no. 21 of 15 April 2004, art. 2, para a).

The following types of risk fall within the category of emergency situations (Ministry of Interior 2005, Regulament privind gestionarea situaților de urgență [Emergency Management Regulations], art. 3):

- floods caused by natural overflows of watercourses, due to increased flows or blockages caused by ice, alluvial and snow avalanches, and leakage from the slopes; 
- dangerous meteorological phenomena: torrential rain, heavy snowfall, thunderstorms and blizzards, ice deposits, frost, glazed frost, early or late frosts, hail and drought (hydrological);

- accidental pollution of the surface and underground water sources and marine pollution in the coastal zone.

The crises and emergencies crises are complex and wide-ranging social phenomena involving the knowledge and terminology of several disciplines: political science, economics, sociology, geology, geography, meteorology, psychology, military art and others.

Due to the fact that virtually, no crisis has evolved, and does not manifest in the present day strictly in the field of human activity, the interdisciplinary character of its analysis is obvious.

The general theory of crises and emergencies capitalises a variety of analytical criteria for their classification and highlights their content and characteristics.

On the whole, it is considered that, for the optimal classification of crises, the following criteria may be used (Udeanu 2012, p. 45):

- after the level, the impact of the situation is to be configured: individual; local, national, zonal, continental and global;

- after the urgency of resolving the emergency situation or capitalising the opportunities offered by it: immediate, urgent, sustained and amplified.

The most common way of describing the characteristics of crises is that based on the criterion of their field of occurrence and proliferation.

However, the new types of hazards and threats require a new, integrative approach combining all the power tools (political, economic, civilian, military, etc.) as well as a strategy on the use of new technologies. In addition, the organisational structure of institutions with responsibilities in the field of human security and public order must respond in a conjugated manner to irregular/hybrid threats.

The desideratum can be achieved only if one realises that in the human security equation, the main problem is the permanent balancing of the relationship between the state and the citizen - the state being responsible for guaranteeing and defending the fundamental rights and freedoms of its citizens (The Constitution of Romania, 2003, art 21, para 1). 
Moreover, at this stage of development, the state, together with its specialist institutions, must be a guarantor of democracy - an important resource of the internal security environment, but also as a manager of all risks within the decision-making process involving firm interventions to mitigate the effects of vulnerabilities, hazards and threats on the social stability (The Romanian National Strategy Regarding Critical Infrastructure Protection, 2011, chapter 2).

In this regard, managing the emergency/crisis situations generated by floods, dangerous meteorological phenomena, accidental hydro technical constructions and accidental pollution implies the following actions: identifying and monitoring, notifying responsible actors, warning the population, assessing, limiting, removing or counteracting the risk factors.

This set of activities and actions must be based on some principles such as (Romanian Government Emergency Ordinance no. 21 of 15 April 2004) ):

a) Forecasting and prevention;

b) The priority of protecting and saving people's lives;

c) Observing human rights and fundamental freedoms;

d) Public administration authorities assuming the responsibility of emergency management;

e) Cooperation at the national, regional and international level with similar bodies and organisations;

f) The transparency of the emergency management activities, so as not to aggravate the effects produced;

g) The continuity and gradualness of the emergency management activities, from the level of the local public administration authorities to the level of the central public administration authorities, depending on their magnitude and intensity;

h) Operability, active co-operation and hierarchical subordination of the components of the National Emergency Management System.

The in-depth analysis of the security environment and the determinations of its possible dynamics imply the study of national security as a macro-system, at the same time with a detailed scientific investigation of its elements considered essential for the promotion and protection of the security interests of the population. From the perspective described above, national security represents the normative, organisational, structural and functional framework for maintaining individual 
and collective security, the protection of critical infrastructures and civil protection, ensuring or restoring public and constitutional order and defending the independence, sovereignty and territorial integrity of Romania.

\section{The role of military structures for the protection of the population in the context of managing an emergency crisis}

As an important component of the national security system, the protection of the civilian population, a responsibility mainly of the Ministry of Internal Affairs (through the General Inspectorate for Emergency Situations), represents an integrated set of specific activities, organisational, technical and operative measures and tasks with a humanitarian and public information character, planned, organised and carried out in order to prevent and reduce the risks of disasters, to protect the population, goods and the environment against the negative effects of emergency situations, armed conflicts and the operative removal of their consequences and to ensure the necessary conditions for the survival of the affected persons (The Romanian National Civil Protection Strategy 2005, chapter 1).

However, military forces can only engage in humanitarian aid activities, humanitarian operations when another cannot do it. This is because these types of missions pose a number of problems in their execution. From our point of view, among the difficulties arising during their accomplishment we mention:

a) humanitarian missions are not rigorously defined;

b) the imprecision of the mandate, which could allow a negative interpretation of the military intervention, albeit a "humanitarian" one;

c) the army does not have as a distinct structure, a specialised unit for humanitarian aid, but due to some services (medical, logistics, CBRN protection / decontamination), certain sufferings of the population affected by a particular situation can be limited;

d) the costs of operations - military structures consume their own budget when they participate in humanitarian actions, and it is a carefully elaborated and very rigorously defined destination. 
An action carried out by military structures is humanitarian only if it is aimed at limiting/halting the sufferings of individuals (Radu 2012). Starting from the premise that a humanitarian act definitely has the purpose stated in the previous statement, we come to the conclusion that the debate is actually focused on means. By analysing the various points of view regarding the question: "what is a humanitarian act?", we can conclude that the means can take distinct forms: military, civil, medical, logistical / protection, subsistence, financial, etc.

There are two opinions on humanitarian interventions. The actors who argue that humanitarian intervention is necessarily peaceful, completely exclude the armed forces as a humanitarian means, while the actors who claim that military means can also be used for humanitarian action, consider military force as a resource for humanitarian action.

In practice, military involvement is useful, in our opinion, in the prevention or cessation of human suffering, in several main directions, namely:

- The military institution of organisation and self-defence, through its capacity for rapid reaction, can ensure the freedom of action of the forces engaged in providing humanitarian aid and maintaining the security of the perimeter, as well as protect the humanitarian corridors (engineering units can intervene in unblocking the communication channels, the military police for monitoring and protection of transport columns, fluidity of traffic, etc.);

- Making availabletoNGOs, engaged in humanitarian activities, theinfrastructure it possesses, in particular, the means of communication and transportation;

- The medical service of the army may, through its specialist personnel and field hospitals, provide the qualified help needed for the civilian-traumatised population;

- Army structures have an area of expertise in the field of explosives and ammunition, putting it to the benefit of the population through actions to decommission unexploded munitions or detonated of obstacles that can indirectly endanger the people's lives or their assets.

Thus, it can be noticed that military actions can be a resource in accomplishing humanitarian goals. 
As a result, we believe that humanitarian interventions use both civilian and military resources. Only in this way can humanitarian interventions conduct actions that might prevent or halt a humanitarian crisis.

At the same time, in the military doctrines in force (Land Forces Operations Doctrine 2004), one of the missions of the military structures is to participate in supporting the state institutions and local authorities during civil emergencies, and if they are employed, we can also refer to the specific support given to the central/local government authorities and population by support operations.

In the support operations, military forces are used to help the civil authorities, when preparing or responding to crises and other special situations beyond their capabilities, by providing basic support, services, means or specialist resources as appropriate.

The purpose of the support operations is to meet, for a limited time, the immediate needs of certain social groups, until the civil authorities can do it without any military assistance. Under extreme or exceptional circumstances, military forces can help ease the situation or directly help those in need. However, military structures must normally assist the civilian authorities or non-governmental organisations in providing specific and necessary assistance.

In the event of calamities or disasters, the national central and local authorities, or those belonging to the host country, are responsible for the restoration of basic services in the affected area. To support their efforts, the empowered constitutional authorities may order the deployment of units or groups of forces.

In our vision, military structures perform similar activities during the rescue operations within the support operations, including:

- Rescue in the event of calamities or disasters - they focus on restoring basic infrastructure elements;

- Humanitarian relief - they focus on securing the vital needs of the supported population. Typically, they run simultaneously.

The main actions that are carried out by military forces during rescue operations should be: search and evacuation, flood control, hazard identification, population and support forces security, distribution of food, production, purification and distribution of water, supplying clothing, heating and cooking fuels, temporary 
housing, transport support, fire extinguishing, medical support, electricity generation, communications and information support, sanitation, repair or demolition of affected infrastructure, restoration or construction of bridges, roads and aerodromes, removing the debris (obstacles) from the supply routes and from the rescue places.

\section{Conclusions}

Regardless of the level of government, be it local, national or supranational, the humanitarian assistance and the protection of population security are the prerogatives of some civilian bodies, while the armed forces have to protect the human communities from military threats, mainly from the external environment.

However, everyday reality, practice and specialist studies have shown that there have been significant changes in this classical division, among which we mention the increase of the role of the military in supporting the tasks of civil administration, amid the diminishing of the danger of international conflicts, the intermingling of military tasks with supporting ones in operations for the protection of the population (at national and international level), a greater integration of the national armed forces in the implementation of the mandates and operations of the supranational organisations that presuppose the humanitarian aid, as well as the approximation of the military operational design and the public order or of ensuring the safety of citizens and their humanitarian assistance.

In addition, the need to implement a civil-military comprehensive approach (civilmilitary integration) is visible not only in military conflicts, but also in all efforts to solve various types of crises and 21st century security challenges. Civil-military integration is a process through which military capabilities together with other civilian capabilities combine to achieve coherent effects.

A comprehensive or integrated task represents a means of work through which problems of major importance are solved, and successful interagency collaboration can substantially contribute to promote the interests of the civilian population. 
Also, an effective civil-military integration will authorise common training and procedures.

It is possible that, in the future, given the increased importance of the humanitarian missions required by various national or multinational military structures, specialist units capable of carrying out these types of tasks with professionalism can be created.

We also underline the fact that the classic differences between military and civilian institutions will not disappear in the near future, so that the civil-military (interagency) integration/cooperation is indispensable at all levels, so that the armed forces will effectively accomplish their support roles within the civil protection and humanitarian operations.

\section{References}

Dicționarul Explicativ al Limbii Române. 2009. Univers Enciclopedic Gold Publishing House, Bucharest.

Dragoman, I., Istrătescu, A.V. and Bulete, V.E., European Humanitarian Operations.

[19 December 2017] http://www.arduph.ro/domenii/operatiuni-de-pace/operatiiumanitare-europene/.

Iacob, D. and Cismaru, M.D., 2002. Organizația inteligentă: 10 teme de managementul organizațiilor. Comunicare.ro Publishing House, Bucharest.

Land Forces Operations Doctrine, 2004. Land Forces Staff, Bucharest, apud, Mungiu, S., Opinii privind modul de acțiune al subunităților (pluton, companie) în operațiile de stabilitateșidesprijin, [8 December 2017] http://www.revista.forter.ro/50_teorie/502tgl/01.htm \#4.

Law no. 346/2006 regarding the Organization and Functioning of the Ministry of National Defense, republished in the Monitorul Oficial Part I no.867 of 28 December 2017, Bucharest.

Neag, M.M. (coordinator), 2009. Securitatea umană în conflictele și crizele internaționale. Universitatea Națională de Apărare "Carol I" Publishing House, 2007, Bucharest.

Radu, D., 2012. Consecvență versus inconsecvență în politica intervențiilor umanitare. In Sfera Politicii Review 4(170). [20 December 2017] http://www.sferapoliticii.ro/ sfera/170/art18-Radu.php

Regulament privind gestionarea situaților de urgență (Emergency Management Regulations), 2005. Ministry of Interior, Bucharest. [19 December, 2017] www.dsu. mai.gov.ro/wp-content/.../Regulament_12_05_2005.pdf 
Romanian Government Emergency Ordinance no. 21 of 15 April 2004, regarding the National Emergency Situation Management System, published in the Monitorul Oficial no. 361 of 26 April 2004, Bucharest.

The Constitution of Romania. 2003. Published in the Monitorul Oficial Part I no. 767, of 31 October 2003, Bucharest.

The Romanian National Civil Protection Strategy. 2005. Published in the Monitorul Oficial no. 600, of 12 July 2005, Bucharest.

The Romanian National Strategy Regarding Critical Infrastructure Protection. 2011. Published in the Monitorul Oficial no. 555 of 4 August 2011, Bucharest.

Udeanu, G., 2012. Managementul securității naționale. "Nicolae Bălcescu” Land Forces Academy Publishing House, Sibiu. 